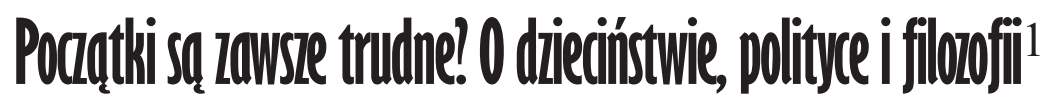

\section{Barbarar Weber}

\section{All llew Beginnings are Difficult: On Chidhlhood, Politis and Philbsopliy}

Abstract: Humans are mainly rational beings and children seem to be "defective creatures". In contrast to that popular and reduced concept of childhood, thinkers like Kant, Arendt and Lévinas explored the more complex anthropological concept of child in its Otherness. They regard childhood as a necessary aspect of the society. Kant in his essay What Does it Mean to Orient Oneself in Thinking? calls for the early encouragement of reason.

Keywords: Arendt, Lévinas, Lipman, childhood, independent thinking, democracy, philosophical education

Idea filozofowania $z$ dziećmi nie jest całkiem nowa: wszak młodzież filozofuje już w Platońskich dialogach. Nawet Immanuel Kant w rozprawie Was heisst: sich im Denken orientieren $?^{2}$ docenia filozofowanie jako jedno z najlepszych ćwiczeń dla młodzieńczego umysłu. Celem takiego ćwiczenia jest uwolnienie umysłu od wszelkiej zależności i ulegania

1 Wykład otwarty wygłoszony przez autorkę na międzynarodowej konferencji pt. „Children Philosophize”, Zakład Etyki UAM, Poznań, 9-11 maja 2011 (konferencja finansowana przez Urząd Miasta Poznania w ramach programu „Akademicki Poznań”). Przekładu i redakcji dokonano za zgodą autorki.

${ }^{2}$ Immanuel Kant, Was heißt: Sich im Denken orientieren (1786), w: tegoż, Was ist Aufklärung? Ausgewählte kleine Schriften, H. Brandt (Hrsg.), Felix Meiner Verlag, Hamburg 1999.

\footnotetext{
* Universytet w Regensburgu, Niemcy e-mail: dr.barbara.weber@web.de
} 
instancjom wyższym, które stają na drodze swobodnemu, samodzielnemu myśleniu. Warto do niego zachęcać już dziesięciolatki, bo jedynie w ten sposób rozum może się stać drogowskazem czy też kompasem dla wolności³ ${ }^{3}$.

Konkretne działania zaszczepiające filozofowanie $z$ dzieć$m i^{4}$ jako model edukacyjny powzięto 40 lat temu w Stanach Zjednoczonych i prawie 35 lat temu w Niemczech. Od tamtej pory idea ta inspiruje najróżniejsze koncepcje teoretyczne, metodyczne i praktyczne. Łączy je chęć wzmacniania w dzieciach samodzielnej, szeroko zakrojonej zdolności myślenia. Chodzi tu nie tylko o myślenie krytyczne, ale także o myślenie twórcze i współmyślenie (analogiczne do współodczuwania). Chodzi ponadto o wzmacnianie w dzieciach poczucia własnej wartości i autonomicznego budowania własnych przekonań. Chodzi też wreszcie o wzmacnianie umiejętności demokratycznych.

Niektóre koncepcje doczekały się dopiero ogólnego zarysu, inne znów rozwinęły się w teorie, metody i narzędzia z prawdziwego zdarzenia, nadajace się do zastosowania w połaczeniu z określoną tematyka filozoficzna. Najpełniej rozwinięte wydaja się koncepcje stworzone przez Matthew Lipmana (klasa jako „wspólnota badawcza”), Ekkeharda Martensa, Leonarda Nelsona (rozmowa wzorowana na dialogu sokratejskim), a także metoda Gustava Heckmanna, praktykowana przez filozofów i pedagogów w Europie Północnej.

Ale co to właściwie znaczy, kiedy mówimy o „filozofowaniu z dziećmi?" Pytanie to stawia Ekkehard Martens w swojej pracy pt. Philosophieren mit Kindern, gdzie stwierdza: „niejasności wokół obu centralnych pojęć, tj. filozofowania i dzieci utrudniają działanie, jakiego byśmy sobie tutaj

3 Zob. też Ekkehard Martens, Philosophieren mit Kindern, Philipp Reclam Verlag, Stuttgart 1999, 53 i n.

${ }^{4}$ Posługuję się tu celowo i konsekwentnie określeniem „filozofowanie z dziećmi”. Jest to pojęcie skupiające wszelkie propozycje wsparte bezpośrednio na treściach, metodach i nastawieniach majacych wzmacniać dziecięca refleksję, kompetencje emocjonalne i praktyczne. Jednorodne nazewnictwo pozwala uniknać nieporozumień, gdy autorzy starają się odróżnić swoje propozycje od cudzych. Należy zatem traktować „filozofowanie z dziećmi” jako odrębne wobec „filozofii dla dzieci”, „dzieci filozofujących”, „rozważań z dziećmi”, „filozofii dziecięcej” itp. 
życzyli" 5. Dlatego najlepiej będzie rozpocząć od przypomnienia, jaka postawę przyjmuje wobec dzieci Lipman i o jaka definicję dziecka bądź dzieciństwa chodzi.

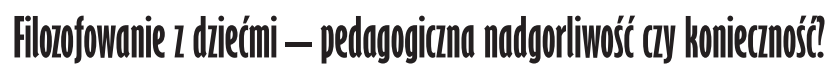

Lipman wychodzi z założenia, że dzieciństwo przynależy do ludzkiej kondycji nie mniej niż pozostałe fazy życia. Mówi: „różnice między perspektywami płci tworzą nieprzekraczalną barierę, uniemożliwiającą mężczyźnie i kobiecie wzajemne doświadczenie perspektyw. Tymczasem różnice między perspektywami dziecięcymi i dorosłymi wręcz zapraszają do wzajemnego doświadczania tego, co w ludzkiej kondycji wielorakie, zamiast do wznoszenia międzypokoleniowych barier, pogłębiania wrogości, represji i posłuszeństwa" ${ }^{\circ}$ Z drugiej strony słychać twierdzenia, że dzieci nie potrafią jeszcze myśleć logicznie i abstrakcyjnie, i dlatego „filozofowanie z dziećmi” to wysiłek daremny. Jednakże Lipman argumentuje tutaj, że w dawnych czasach nie podawano dzieciom i zwierzętom środków przeciwbólowych, uważając, że nie czują bólu, i tak samo w dzisiejszych czasach uważa się, że brak im zdolności logicznego myślenia ${ }^{7}$. Na dowód przytacza się najczęściej badania prowadzone przez Jeana Piageta, a raczej ich jednostronna dezinterpretację, wedle której dopiero po ukończeniu jedenastego roku życia dzieci zdolne są wnioskować i myśleć logicznie ${ }^{8}$. Lipman natomiast słusznie wykazuje, że Piaget, piszacc o orientacyjnych stadiach rozwoju, starał się jedynie zachęcić nauczycieli do tego, żeby dostosowali swoje metody nauczania do stadiów rozwoju logicznego u dzieci, a nie na odwrót. Niestety,

${ }^{5}$ E. Martens, Philosophieren mit Kindern, dz. cyt., s. 25.

${ }^{6}$ Matthew Lipman, Thinking, Children, Education, Upper Montclair, New York 1980, s. 143.

7 M. Lipman, Ann M. Sharp, Frederick S. Oscanyan, Ethical Inquiry, IAPC, New York 1977, wyd. II, IAPC \& UPA, Rowman and Littlefield, New Jersey 1985, s. 408.

8 Jest to naturalnie skrócona interpretacja rozległych badań przeprowadzonych przez Piageta, którego teoria także podlegała modyfikacjom. Na przykład późny Piaget jest nieporównywalny z wczesnym, już częściowo zdezaktualizowanym. 
niemal wszyscy zrozumieli rady Piageta opacznie: nie chodzi mu wcale o przyspieszanie edukacji myślenia. Co gorsza, niektórzy naiwni czytelnicy Piageta sugeruja, że skoro we wczesnym okresie dzieci rozumuja w sposób konkretny, to instrukcje czy zadania kierowane do nich przez nauczycieli też muszą być konkretne. Jest to wysoce wattpliwe z punktu widzenia metodyki resp. psychologii edukacyjnej ${ }^{9}$. Gdyby uznać to błędne przekonanie za słuszne, musielibyśmy analogicznie (i absurdalnie) przyjaćć, że nie należy rozmawiać z małymi dziećmi, ponieważ one jeszcze nie umieja mówićn ${ }^{10}$.

Dlatego Lipman dowodzi dalej, że „traktujemy dzieci tak, jakby były niezdolne do deliberacji filozoficznej, ponieważ zachowuja się tak, jakby nie były do niej zdolne" ${ }^{11}$. W $1971 \mathrm{r}$. hipoteza Lipmana potwierdziła się w badaniach: przeprowadzono Kalifornijski Test Dojrzałości Umysłowej (California Test of Mental Maturity) w grupie dzieci z klasy średniej, białych i kolorowych. Po dziewięciu tygodniach lekcji filozofowania z dziećmi $(2 \times 40$ minut tygodniowo $)$ w grupach pilotażowych wskaźnik dojrzałości umysłowej wzrósł znaczaco $(\mathrm{p}=0,1 \%)$. W porównaniu z grupa kontrolną dzieci filozofujące zyskały przewagę umysłową sięgajaccą aż dwudziestu siedmiu miesięcy. Efekt ten okazał się długofalowy: nawet po kilku latach grupa pilotażowa nadal wykazywała taka sama przewagę wobec grupy kontrolnej ${ }^{12}$.

Lipman jest przekonany o tym, że skoro (a) bycie dzieckiem to część bycia człowiekiem, to (b) dzieci sa istotami społecznymi, które uczą się od siebie nawzajem jako uczestnicy demokratycznej wspólnoty (John Dewey). Ponadto skoro (c) dzieci nie sa irracjonalne i mniej zdolne do udziału w dyskursie od dorosłych, to (d) sa one istotami potencjalnie racjonalnymi, nawet jeśli wymagają wsparcia dorosłych. Jest on też przekonany o tym, że ludzie muszą się nauczyć samodzielnego myślenia już w dzieciństwie, aby mogli się później włączyć do procesów politycznych. „Jeśli naprawdę chcemy

9 M. Lipman, Thinking..., dz. cyt., s. 376.

${ }^{10}$ Tamże, s. 376.

${ }^{11}$ Tamże, s. 378.

${ }^{12}$ Por. tamże, s. 381 i n. Tego rodzaju metodyczne wprowadzenia do pojęcia filozofii moga wydać się o tyle problematyczne, że dialog filozoficzny daleki jest od wpajania dzieciom „właściwego myślenia”. 


\section{Barbara Weber |}

mieć demokrację, to najpierw musimy się sami nauczyć tego, jak uczyć dzieci samodzielnego myślenia"13.

Niemniej jednak Lipman nie podał jakiejś jednoznacznej i sztywnej „teorii dzieciństwa”, z której można byłoby wywodzić określone czy zalecane postawy etyczne bądź pedagogiczne wobec dzieci. Dlatego chciałabym pokazać, w jaki sposób możemy zrekonstruować nasz obraz czy ideę dzieciństwa tak, by móc podjać dydaktycznie owocny dialog filozoficzny z dziećmi. Nie chodzi tu jednak o jakieś „prawdy ostateczne", a tylko o refleksje wstępne i elementarne, które raczej ukazuja (zamiast ukrywać pod warstwa gładkich ogólników) całą złożoność sytuacji.

\section{Hermenentutya dieciństwa a pedagogikn terániejsiosici}

W jednym ze swoich wykładów o pedagogice (1828) Friedrich Schleiermacher poddał w wątpliwość to, czy teraźniejszy moment ludzkiego życia może być używany jako środek do celu ${ }^{14}$. Często bowiem działalność pedagogiczna wiąże się z poświęcaniem teraźniejszości na rzecz przyszłości. Poświęca się ja na objaśnianie, napominanie i wychowanie dziecka jako docelowo „człowieka rozumnego”. Ale takie myślenie zakłada traktowanie dziecka jako „istoty wybrakowanej”, jako „człowieka niepełnego” i „niedoskonałego”, który dopiero w przyszłości, dzięki wychowaniu i edukacji, stać się ma „człowiekiem właściwym”.

Nasuwa się tu jednak takie oto pytanie: czy obecne pokolenie może sobie uzurpować, czy zgoła kolonizować przyszłość dzieci, wychowując je wedle zalecanych norm i wartości. A może bycie dzieckiem jest właśnie - jak pokazuje to Hannah Arendt - politycznym apelem o zaniechanie takiej uzurpacji? W dyskusji z Arendt pokażemy, że dialog i wychowanie nierozerwalnie przynależą do ontologicznej przestrzeni działania politycznego, i dlatego nie powinny być przedmiotem uzurpacji. W przeciwnym razie okradamy dzieci z ich politycznego, czyli źródłowo ludzkiego wymiaru, jakim jest natality.

${ }^{13}$ M. Lipman, Thinking..., dz. cyt., s. 35.

${ }^{14}$ Friedrich Schleiermacher, Pädagogische Schriften, t. 1, E. Weniger (Hrsg.), wyd. II, Schöningh Verlag, Düsseldorf-München 1988, s. 46. 
Aby lepiej zrozumieć sedno tego problemu, zwróćmy się do Arystotelesa i Martina Heideggera, wielkich nauczycieli Hannah Arendt. Arystoteles pojmował czas jako bezosobowy arithmos kineseos resp. numerus motus ${ }^{15}$ (liczbę dynamiczna), tymczasem Heidegger pojmuje czas jako ludzkie jestestwo (Dasein), a ściślej - jako bycie ku śmierci ${ }^{16}$. Wedle Heideggera w jestestwie samoistnie rozwijają się trzy wymiary, trzy „ekstazy” czasu: przeszłość, teraźniejszość i przyszłość. Dlatego mój własny czas jest czasem każdorazowo synchronicznym. Czas jestestwa jest suwerenny. To nic innego aniżeli wolność. Ta zaś aktualizuje się w aktywności.

W swej książce Vita activa ${ }^{17}$ Arendt podzieliła ludzką aktywność na trzy formy: pracę, wytwarzanie i działanie. Każda z tych form znów rozgrywa się w różnym modusie czasowym $^{18}$. Jedne modi czasu wpisane są w cykl przyrodniczy, inne tworzą linearny czas właściwy człowiekowi i tylko człowiekowi. Cykliczność jest typowa dla monotonnego, powtarzalnego stawania się i przemijania w przyrodzie. Dlatego też codzienna praca jest najniższą w porządku ludzkich aktywności. Arendt rozumie pracę jako ciagła produkcję i konsumpcję umożliwiajace po prostu przetrwanie. Praca jest tutaj czymś na wskroś prywatnym, bo chodzi w niej tylko o podtrzymanie ekonomii ludzkiego ciała.

Z kolei wytwarzając i zmieniając przedmioty (środkowa pozycja w hierarchii aktywności), kreujemy pewnego rodzaju trwałość i ciagłość. Krzesło, stół czy dom trwają dłużej niż ludzkie życie. Potencjalnie zadaniem owego sztucznego świata (świata jakościowo nowego w stosunku do zastanej przyrody i właściwych jej zabiegów) jest więc stworzenie człowiekowi stabilnego, fizycznego domostwa, które ostanie się cyklom przyrody i pracy. Dzięki jego istnieniu dzieci przychodzą na świat w otoczeniu względnie trwałym i pewnym: w domu, w mieście itp. Z tym wytworzonym światem wiąże

${ }^{15}$ Arystoteles, Fizyka, 219 b2.

${ }^{16}$ Por. Martin Heidegger, Bycie $i$ czas, przeł. B. Baran, PWN, Warszawa 2001.

${ }^{17}$ Hannah Arendt, Vita acitva oder vom tätigen Leben, GRIN Verlag, München 2002.

18 Tamże, s. 28 i n. 
się również kultura, czyli nawyk i tradycja używania narzędzi i codziennych przedmiotów.

Jednak zarówno praca, jak i wytwarzanie należą do sfery prywatnej i nie sa jeszcze tym, co dla ludzkiej egzystencji najwłaściwsze. Wedle Arendt najwyższą formą aktywności jest bowiem działanie. Jako takie, należy ono do sfery publicznej i w przeciwieństwie do tamtych dwóch rozgrywa się w świecie dzielonym przez ludzi, w materii słów i czynów. Działanie dokonuje się w czasie linearnym, który jest specyficznie ludzkim modusem czasowości. Dzięki niepowtarzalności i nieprzewidywalności działania człowiek jest w stanie przerwać cykl czasu przyrodniczego i tradycję. Człowiekowi dana jest bowiem możność zaczynania od początku: a jest ona dana razem $\mathrm{z}$ faktem, że człowiek się rodzi (natality). Ta właśnie możność jest centralnym punktem w antropologii Arendt: „ponieważ każdy człowiek z racji bycia urodzonym uosabia inicjację (initium), początek i bycie nowym przybyszem w świecie, ludzie potrafią podejmować inicjatywę, zaczynać od początku, jako nowicjusze dajacy początek czemuś nowemu"19. Punktem wyjścia wszelkiej historii jest pierwszy krzyk dziecka, źródło wszelkich możliwości. Choć Arendt zalicza wychowanie i wszelkie zajęcia uchodzace tradycyjnie za kobiece do sfery prywatnej, dowodzi ona, że dzieciństwo z racji swej ontologicznej istoty wyrasta ponad prywatność: $\mathrm{w}$ dzieciństwie bowiem tkwi poczatek człowieka. Innymi słowy, narodziny człowieka sa jako takie już same przez się aktem na wskroś politycznym, bo oznaczają nowy początek w świecie istniejaccym, zastanym. Narodziny przerywaja cykl przyrodniczy, wszelki utarty porządek, ponieważ w świecie zapoczątkowane zostało coś nowego.

Nie tylko poczęcie dziecka, lecz także wychowanie jest aktem o wielkim potencjale politycznym. Natomiast jeżeli dzieci stają się zakładnikami przeszłości, to polityczny ładunek ich egzystencji zostaje niejako rozbrojony. Przyszłość zostaje zaanektowana przez przeszłość. Przestrzeń polityczna (w tym sensie, w jakim polityczność pojmuje Hannah Arendt) powstaje zaś wtedy, gdy ludzie przychodzą na świat istniejaccy i utrwalony, ale zarazem otwarty na to, co przyszłe i nowe. Bo taki i tylko taki świat jest właściwy dla nowicjuszy: w nim to dzieci mogą być dziećmi.

${ }^{19}$ Tamże, s. 215. 
Dzięki przemianie pokoleń ofiarowujemy dzieciom nasza przeszłość jako tradycję, żeby urodziły się w świecie stabilnym. Od dzieci zaś otrzymujemy inny dar: ich czas, ich początek, które zdolne są uwolnić i wybawić nas samych od błędów przeszłości. Ten dialog między początkiem a tradycją można też nazwać hermeneutycznym oswajaniem własnej historii czy biografii ${ }^{20}$. Z jednej strony dzieci uczą się dzięki doświadczeniom dorosłych, a z drugiej - interpretują świat na nowo i wyrywają się ku przyszłości. Otwierają nowy dostęp do świata, taki, jakiego nie wskazali im dorośli. Ta nowa interpretacja może polegać np. na tym, że dzieci z krzesła robią sobie dom albo kryjówkę. Może się zdarzyć, że dzieci na nowo rekonstruuja zdarzenia polityczne (np. przez uwolnienie od nienawiści czy resentymentu).

Obydwa sposoby: przywiazywanie się i uwalnianie, to zasadniczo „antidotum na nieodwołalność” działania u Arendt: „antidotum na nieodwracalność czegoś, co się uczyniło, nie wiedząc i nie mogąc wiedzieć, co się czyni, tkwi w ludzkiej zdolności do wybaczania. A znów antidotum na nieprzewidywalność, chaos i niepewność tego, co przyszłe, tkwi w zdolności obiecywania, w dawaniu i spełnianiu obietnic"21. Albo, jak powiedział Fryderyk Nietzsche: „człowiek to zwierzę, które potrafi obiecywać" (prawda i kłamstwo w sensie pozamoralnym). Albowiem tylko wówczas, gdy przyszłość pozostaje przestrzenią otwarta, dzieci mogą nam dopomóc w przecięciu pępowiny, która łączy nas z minionymi czynami: wszak uosabiają nowy początek w samym środku historii. Czas dziecięcy wsącza się w strumień naszego czasu i unosi ze soba w otwarty, wolny i niezapełniony jeszcze wymiar, jakim jest przyszłość. Następuje zmiana pokoleń. Jednocześnie dzieci sa naszą obietnicą i nadzieją na to, że będzie „lepiej” i że wszystko potoczy się „dalej”.

${ }^{20}$ Przykładem może być tragedia historyczna: Holocaust, a także aktualny konflikt izraelsko-palestyński. Obecnemu pokoleniu trudno się uwolnić, jest ono nadal silnie uwikłane w przeszłość. Natomiast dzieci są otwarte i zdolne zdecydować się na nowy początek, o ile nie będzie on dla nich przygotowywany rękoma obecnego pokolenia (np. z pomoca propagandy czy manipulacji).

${ }^{21}$ H. Arendt, Vita activa..., dz. cyt., s. 301. 


\section{0| Barbara Weber |}

Zgoła inaczej niż Arendt, dla której czas linearny zazębia się z intersubiektywnym wymiarem działania i mimo to pozostaje każdorazowo i niezmiennie moim własnym czasem, Emmanuel Lévinas zgłębia dynamikę dwóch suwerennych czasów. Chodzi o etyczny wymiar czasowości, który bierze się stąd, że inna istota (tutaj: dziecko) ma przyszłość, tzn. jest wolna. Lévinas przygląda się przesmykowi, którym dziecko wnika jako Obcy do mojego czasu. „Przyszłość jest czymś nieuchwytnym. Po prostu nachodzi nas i bierze w posiadanie. Przyszłość jest tym, co inne. [...] Czas dokonuje się w sytuacji twarzą w twarz. Nakładanie przeszłości na przyszłość to nie jest akt pojedynczego, samotnego podmiotu. To jest relacja międzypodmiotowa"22. Tam, gdzie Inny wkracza w mój czas, pojawia się rysa, pęknięcie: cudzy czas nie poddaje mi się, cudza wolność staje mi na drodze ${ }^{23}$. „Czyjaś obecność zmusza mnie do odpowiedzialności wobec tego, co się wydarza. On patrzy, a ja jestem na cenzurowanym: nie ma odwrotu. Zostałem zakładnikiem. Ten wzrok nie ścierpi, żebym przyją moja przeszłość ot tak, po prostu. [...] Przyjmuję zatem odpowiedzialność"24.

Owa „diachronia” zachodzi w każdym akcie, w każdym poruszeniu wobec innego człowieka, a pełnię uzyskuje w rodzicielstwie. Dziecko bowiem to bardzo szczególny Obcy. Lévinas powiada: „Syn nie jest po prostu moim dziełem, jak wiersz lub przedmiot. Nie jest również moją własnością. Ani kategorie władzy, ani kategorie wiedzy nie opisują mojej relacji z dzieckiem. Płodzenie przez Ja nie jest ani przyczyna, ani panowaniem. Nie mam mojego dziecka, lecz jestem moim dzieckiem. Ojcostwo jest relacją z obcym, który, choć pozostaje obcy, choć jest innym człowiekiem - [...] jest mna. [...] W samym istnieniu pojawia się wielość i transcendencja. [...] Druga strona ojcostwa - synostwo, relacja między synem i ojcem, oznacza jednocześnie relację zerwania i nawiązania ${ }^{25}$.

${ }^{22}$ Emmanuel Lévinas, Die Zeit und der Andere, Taschenbuch Verlag, Hamburg 1989, s. 48, 51.

${ }^{23}$ E. Lévinas, Totalität und Unendlichkeit, Verlag Karl Alber, München 1993, s. 438.

${ }^{24}$ E. Lévinas, Jenseits des Seins oder anders als Sein geschieht, Verlag Alber, München 1998, s. 311.

${ }^{25}$ E. Lévinas, Całość i nieskończoność, przeł. M. Kowalska, PWN, Warszawa 1998, s. 335-336. 
Ucząc się kultury w działaniu i korzystaniu z przedmiotów, dzieci rozwijają swoja podmiotowość, ale silnie wkraczają też w nasze życie. Jednak przyszłość rodzicielska nie jest przyszłością dziecka. Każde dziecko to żywy dowód zerwania z historią. Gdy dla nas jest już za późno, odpowiedzialność przejmują dzieci. Dzieci dziedziczą historię w formie narracji, czyli opowieści o tym, skąd przychodza, kim sa i dokąd zmierzaja. Owo dziedziczenie jest jednak aktywne i dlatego zrywa ze znaczeniami pierwotnymi, utartymi. Historia traci ciagłość. A jeśli spróbujemy zawłaszczyć dla niej przestrzeń tego, co Nowe, historia splącze się nieodwracalnie. „Transcendencja jest czasem i zmierza ku Innemu. Ale Inny nie jest kresem, nie zatrzymuje ruchu Pragnienia. Inny, którego pragnie Pragnienie, jest także Pragnieniem, transcendencja transcenduje ku bytowi, który sam jest transcendencja - oto na czym polega prawdziwa przygoda ojcostwa w transsubstancjalizacji, która pozwala wyjść poza zwykłe powielanie możliwości nieuchronnie starzejaccego się podmiotu"26.

Dla międzypokoleniowego dialogu znaczyłoby to, że w relacjach z dziećmi zdani jesteśmy na inny czas, na cudza przyszłość, a zarazem stoimy na gruncie przeszłości. Jednak pedagodzy najczęściej prowadzą z dziećmi dialog wertykalny zamiast horyzontalnego. Jako dorośli wyjaśniaja dziecku świat, daja porady i zadaja pytania, na które znają już odpowiedzi ${ }^{27}$. Bernhard Waldenfels i Käte Meyer-Drawe tak charakteryzuja wertykalny dialog między pedagogiem i dziećmi: „przepaść pomiędzy Swoim i Obcym pogłębia się, im bardziej dyskurs staje się odtwórczy i dopasowany. Dyskurs tego rodzaju ogranicza się już tylko do powielania, reprodukowania i przekazywania znaczeń sfa-

${ }^{26}$ Tamże, s. 325-326.

${ }^{27}$ Garreth Matthews wskazuje w tym kontekście na zasadnicze nieporozumienie przypisywane metodzie sokratejskiej: wielu rozumie tę metodę tak, jakby pytanie kierowane do młodego człowieka (ucznia, studenta) miało wydobyć z niego „właściwy wynik” czy też „jedynie słuszną odpowiedź” (por. dialog Platona Menon), znaną już uprzednio nauczycielowi. To jest jednak uproszczenie. Prawdziwie sokratejski nauczyciel nie zna odpowiedzi i nie zadaje „fałszywych” pytań. Por. Garreth Matthews, Socratic Perplexity and the Nature of Philosophy, Overstock Publ., New York 1999. 


\section{1 Barbara Weber |}

brykowanych wcześniej”28. Odtwórcze, reproduktywne nastawienie pedagoga pociaga za soba negację i zapoznanie akurat tego wymiaru dzieciństwa, który Arendt nazwała politycznym w głęboko ludzkim, egzystencjalnym sensie.

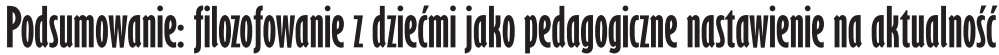

Z racji opisanych wyżej zagrożeń i zawłaszczeń dialog filozoficzny powinien stać się sposobem na spotkanie dorosłych i dzieci w planie horyzontalnym, czyli takim, który pozwoli dzieciom działać i oddziaływać żywo i autentycznie na historię, która dzieje się teraz. Jednocześnie dialog ten musi otwierać je ku przyszłości poprzez wyzwalanie postawy zdziwienia, postawy krytycznej i postawy pytającej: albowiem stawianie pytań filozoficznych i poddawanie ich pod dyskusję jest wolne od wszelkich wprzódy założonych treści i znaczeń, od stereotypowych i gotowych wzorców komunikacji i porozumiewania się. $\mathrm{W}$ tym dialogu nie ma miejsca dla lepiej wiedzacych. Ten, kto „wie”, wcale nie ma przewagi nad innymi: filozofujaccy dyskutanci mogą wpaść na wiele różnych odpowiedzi. Dlatego dorośli w filozoficznej dyskusji z dziećmi muszą być gotowi na to, by wystawić się na próbę, by uczestniczyć we wspólnym tworzeniu sensu i wspólnym osądzaniu czy ocenianiu tego, co w dziecięcej refleksji nowe, dziwne czy obce. Podobnie piszą o tym Waldenfels i Meyer-Drawe: „przepaść między Sobością i Obcością zmniejsza się, im bardziej twórczy jest dyskurs i im więcej wnosi on w budowanie nowych podstaw rozumienia, im bardziej zmienia wyznaczniki (rozumienia), zamiast dopasowywać się do nich" ${ }^{29}$. Oznacza to, że w rozmowie realizujacej obydwa te założenia i będącej polem dla powstawania nowych znaczeń i sensów między dzieckiem a dorosłym powstaje coś w rodzaju chiazmu (ein Chiasmus zwischen Kind und Erwachsenem). Chodzi o skrzyżowanie czy też „szew” łączacy aktualność z przyszłościa, o miejsce, w którym te dwa wymiary

${ }^{28}$ Käte Meyer-Drawe, Bernhard Waldenfels, Das Kind als Fremder, „Vierteljahresschrift für wissenschaftliche Pädagogik” 1988, Nr. 46, s. 275.

${ }^{29}$ Tamże, s. 275. 
wzajemnie na siebie zachodza. Dorośli przywiąują dzieci do przeszłości poprzez przekazywanie tradycji. Z drugiej strony dzieci odwiązują i uwalniają dorosłych od przeszłości za sprawą zaczynania od początku i rzucaja - by posłużyć się piękną metafora - „wędkę nadziei” na otwarte wody przyszłości.

Konfrontacja dokonujaca się w rozmowie filozoficznej może jednak prowadzić na manowce ${ }^{30}$. Atoli dopiero w takim spotkaniu, kiedy Inne nas zaskakuje i zdumiewa, dzieci staja się równoprawnymi, choć mimo wszystko nie do końca równymi partnerami dialogu.

Pedagog (zgodnie z grecką etymologia słowa: paidagogós, czyli ten, który wskazuje im drogę do domu) musi więc zrezygnować z „pozycji przewodniej” i stać się „towarzyszem drogi”: kimś, kogo darzy się zaufaniem i kto podąża razem z dzieckiem niczym druh droga, której żaden z nich jeszcze nie zna. Jedynie taka postawa dydaktyczna i taki rodzaj spotkania są w stanie odnowić i zaktualizować polityczny wymiar dzieciństwa. Dzieciństwo nie jest bynajmniej jakimś dopiero „przedpolitycznym stadium człowieczeństwa”. Wręcz przeciwnie, jest ono najpierwszym warunkiem tego, abyśmy w ogóle mogli mówić o jakiejkolwiek politycznej przestrzeni ludzkiego działania, zrodzonego z wolności tego, kto moca własnych narodzin przeznaczony jest przyszłości.

\section{Bibliografia}

Arendt H., Vita acitva oder vom tätigen Leben, GRIN Verlag, München 2002.

Arystoteles, Physik, Felix Meiner Verlag, Frankfurt/M. 2003.

Heidegger M., Sein und Zeit, Max Niemeyer Verlag, Tübingen 2001.

Kant I., Was heißt: Sich im Denken orientieren (1786), w: H. Brandt (Hrsg.), Was ist Aufklärung? Ausgewählte kleine Schriften, Felix Meiner Verlag, Hamburg 1999.

${ }^{30}$ Matthews opisuje, jak wielkim przeżyciem były dla niego rozmowy o strachu, prowadzone z dziećmi z getta, por. G. Matthews, Socratic Perplexity..., dz. cyt., s. 14. 


\section{Barbara Weber |}

Lévinas E., Die Zeit und der Andere, Taschenbuch Verlag, Hamburg 1989.

Lévinas E., Jenseits des Seins oder anders als Sein geschieht, Verlag Alber, München 1998.

Lévinas E., Totalität und Unendlichkeit, Verlag Karl Alber, Freiburg-München 1993.

Lipman M., Thinking, Children, Education, Upper Montclair, New Jersey 1980.

Lipman M., Sharp A.M., Oscanyan F.S., Ethical Inquiry, IAPC, New York 1977, wyd. II, IAPC, UPA, Rowman \& Littlefield, New Jersey 1985.

Martens E., Philosophieren mit Kindern, Philipp Reclam Verlag, Stuttgart 1999.

Matthews G., Socratic Perplexity and the Nature of Philosophy, Overstock Publ., New York 1999.

Meyer-Drawe K., Waldenfels B., Das Kind als Fremder, „Vierteljahresschrift für wissenschaftliche Pädagogik" 1988, No. 46.

Schleiermacher F., Pädagogische Schriften, Bd. 1, E. Weniger (Hrsg.), wyd. II, Schöningh Verlag, Düsseldorf-München 1988.

Przekład z języka niemieckiego i redakcja: Ewa Nowak 